\title{
Mapping debris flow susceptibility using analytical network process in Kodaikkanal Hills, Tamil Nadu (India)
}

\author{
Evangelin Ramani Sujatha ${ }^{1, *}$ and Venkataramana Sridhar ${ }^{2}[$ \\ ${ }^{1}$ Centre for Advanced Research on Environment, School of Civil Engineering, SASTRA University, \\ Thanjavur 613 401, India. \\ ${ }^{2}$ Biological Systems Engineering Department, Virginia Tech, Blacksburg, VA 24061, USA. \\ *Corresponding author.e-mail: r.evangelin@gmail.com
}

MS received 5 October 2016; revised 3 May 2017; accepted 7 June 2017; published online 23 November 2017

Rapid debris flows, a mixture of unconsolidated sediments and water travelling at speeds $>10 \mathrm{~m} / \mathrm{s}$ are the most destructive water related mass movements that affect hill and mountain regions. The predisposing factors setting the stage for the event are the availability of materials, type of materials, stream power, slope gradient, aspect and curvature, lithology, land use and land cover, lineament density, and drainage. Rainfall is the most common triggering factor that causes debris flow in the Palar subwatershed and seismicity is not considered as it is a stable continental region and moderate seismic zone. Also, there are no records of major seismic activities in the past. In this study, one of the less explored heuristic methods known as the analytical network process (ANP) is used to map the spatial propensity of debris flow. This method is based on top-down decision model and is a multi-criteria, decision-making tool that translates subjective assessment of relative importance to weights or scores and is implemented in the Palar subwatershed which is part of the Western Ghats in southern India. The results suggest that the factors influencing debris flow susceptibility in this region are the availability of material on the slope, peak flow, gradient of the slope, land use and land cover, and proximity to streams. Among all, peak discharge is identified as the chief factor causing debris flow. The use of micro-scale watersheds demonstrated in this study to develop the susceptibility map can be very effective for local level planning and land management.

Keywords. Debris flow; watershed; GIS; modelling; mapping; analytical network process (ANP).

\section{Introduction}

Rapid debris flows, a mixture of unconsolidated sediments and water moving at speeds $>10 \mathrm{~m} / \mathrm{s}$ (Hungr et al. 2008) are the most destructive water related mass movements that affect hill and mountain regions in an extensive range of morphoclimatic environments. A study has been carried out to assess the susceptibility of debris flow in Palar watershed which is located in Kodaikkanal hills, a part of Western Ghats in south India (figure 1). Numerous debris flow events are caused by prolonged and intense rainfall in the Kodaikkanal hills, particularly during the north-east monsoon season between September and November (Sujatha et al. 2012; Sujatha and Rajamanickam 2015). Scientific records of debris flow events are not maintained in the government departments and there is not much published literature exclusively on debris flow. Few authors like Sujatha and 


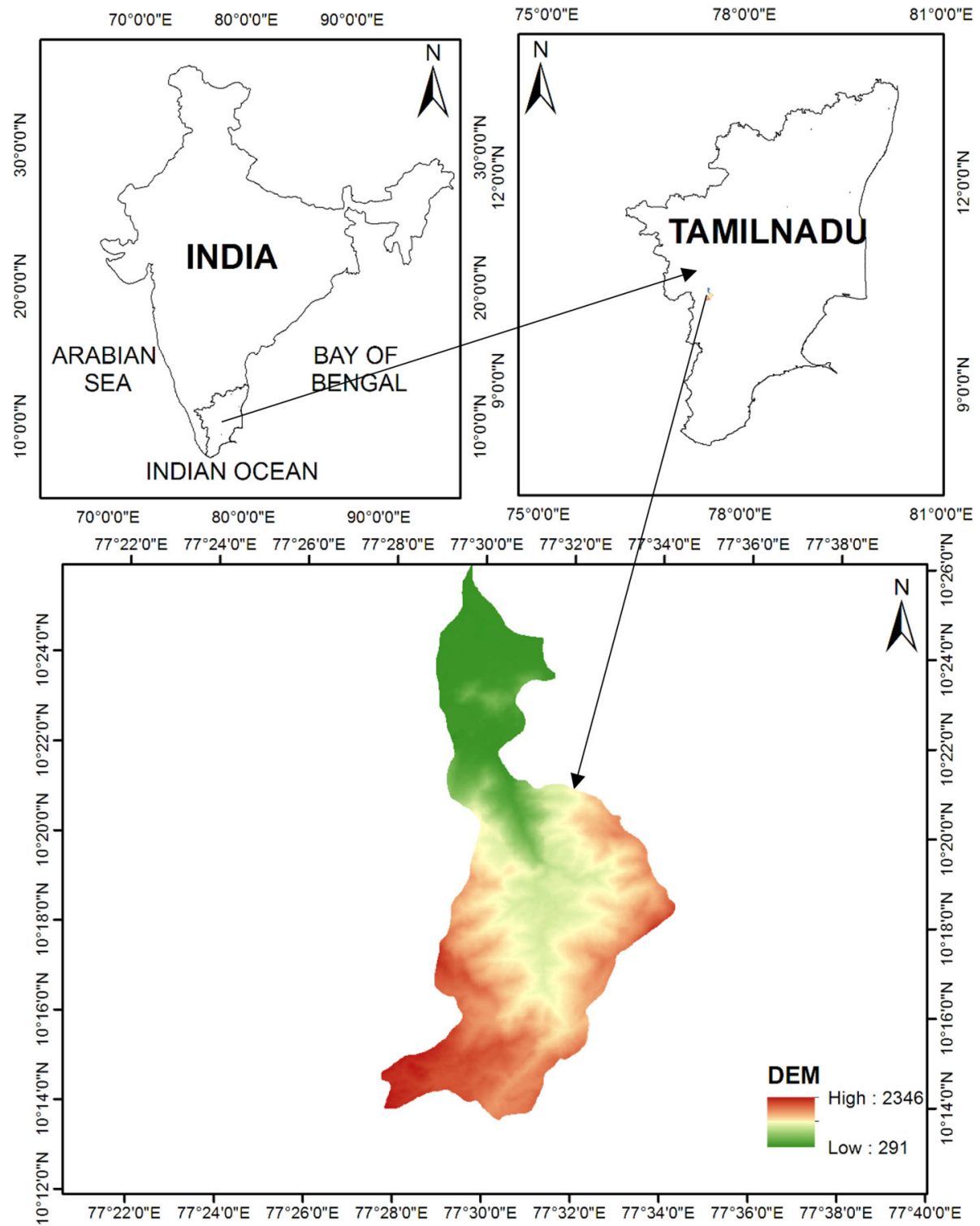

Figure 1. Location map of Palar subwatershed and its digital elevation model showing the higher elevations in the south and drainage to the north.

Rajamanickam (2011, 2015) and Sujatha et al. (2012) have worked on spatial mapping of landslides in Kodaikkanal which include debris flow incidences. Information collected from field surveys, local community and records of compensation paid to farmers on account of loss of crops due to debris are used to generate the debris flow database. Debris flow affects infrastructure such as roads, power transmission lines, plantations, settlements and at rare events disrupts road connectivity between the hill town and the plains. No major injuries or loss of life was reported due to debris flow in this region, but there was considerable disruption to local and tourist traffic as well as cargo carriers. The hill road was closed to traffic for nearly three days as per the reports of the farmers and residents living in Vadakauchi and Kumburvayal villages where the event occurred in 2009. Serious injuries to people, major disruption of traffic and significant damages to houses were observed in 2014 August event that occurred in Indranagar, Kodaikkanal town. These observations were made during the site inspection and the damages were assessed first hand. Major loss of plantation land was reported in the 2014 October event in Vadakaunchi village. Information on this debris flow was collected from the local residents and a site inspection was subsequently carried out to assess the damage. Though large debris flow events that affect the major roads are rare, the impairment of transportation infrastructure has profound economic and social impacts. 
And also, there is a substantial potential for these events to cause serious injury or loss of life, particularly during the tourist season.

Several methods are available for identifying and mapping landslide and debris flow susceptibility (Aleotti and Chowdhury 1999; D'Ambrosio et al. 2006; Guzzetti et al. 2006; Keefer and Larsen 2007; Lucà et al. 2014; Althuwaynee et al. 2015). Susceptibility maps show the spatial propensity to slope failure but do not exhibit the probability of occurrence as in the case of hazard maps (van Westen et al. 2006; Fell et al. 2008). There are two broad approaches to susceptibility mapping direct and indirect. The direct approach involves extensive field study and mapping in the debris flow source area. This approach is limited to small study area or specific debris flow sites. The indirect approach includes probabilistic, statistical and heuristic models to map susceptibility and assumes that the spatial distribution of landslides or debris flow is determined by a set of geo-environmental conditions that control the occurrence of future slope failures based on the past slope failure occurrences (Blahut et al. 2010).

In Kodaikkanal, the lack of detailed slope failure inventory maps restricts the use of probabilistic or statistical models. Heuristic method can fill this gap of limited availability of less detailed inventory maps by making use of the expert judgment. In this study, one of the seldom heuristic methods known as the analytical network process (ANP) is used to map the spatial propensity of debris flow. It is an extension of analytic hierarch process (AHP) developed by Saaty (1980). A network model like ANP with dependence and feedback improves the priorities derived from the expert judgments and makes prediction much more accurate (Saaty 1980) and is a better option in areas dealing with unstructured or complex decision problems. ANP has been a commonly adopted tool in the areas of industrial management, economics and finance, forest management, construction planning and highway planning (Neaupane and Piantanakulchai 2006), but has found very limited use in geo-engineering. But, it has much scope for use in geo-engineering, particularly in modelling natural hazards as it provides a more flexible platform for combining the factors causing the hazard and allows to model the interdependence of factors causing the hazard. It allows the inclusion of expert knowledge and also gives quantative results to easily assess and comprehend the magnitude of hazard and its variation in the study area. The most significant limitation of ANP is that the complexity of the network escalates exponentially with the increase in the number of factors and the interdependency between the factors, as this increases the number of pairwise comparisons. The objective of this study is to map debris flow susceptibility using ANP model and observe the effect of inter- and intradependence of the selected environmental factors i.e., the dependency of the selected factors with each other in a cluster (intra-dependence) and outside the cluster (inter-dependence).

\section{Materials and methods}

\subsection{Study area}

The Palar subwatershed is a part of the Western Ghats and covers an area of $113.81 \mathrm{~km}^{2}$ (figure 1). It falls in the Shanmukha Nadi Watershed, a segment of Cauvery basin and drains into the Bay of Bengal. The area experiences high annual rainfall (1650-1800 mm) and receives rainfall during both north-east and south-west monsoons. Highest rainfall is recorded between September and November.

Winter is between December and February, but rainfall is scarce between January and March. Summer is between March and April and rainfall is heavy in April-May. The climate is of a temperate type with an average maximum and minimum temperatures of $17^{\circ}-25^{\circ} \mathrm{C}$ and $5^{\circ}-12^{\circ} \mathrm{C}$. The study area forms a part of the Palani hills in the northern Madurai block which essentially comprises of charnockite apart from small outcrops of granite and cordierite-garnet-spinel-sillimanite migmatites represent metapelites. The northern tip shows formations of fissile hornblende biotite gneiss of Khondalite group. Charnockites are inferred to have crystallized at $2689 \pm 26 \mathrm{Ma}$ and $2521 \pm 13$ Ma (Plavsa et al. 2012). The origin of charnockite is marked by the events of significant magmatism in Neoarchaean and crustal growth in the northern part of the Southern Granulite Terrane, including the southernmost part of the Dharwar Craton, Salem Block (Bhaskar Rao et al. 1996, 2003; Harris et al. 1996; Ghosh et al. 2004; Tomson et al. 2006; Clark et al. 2009). Bedrock geology of Palar subwatershed is fairly monotonous with charnockite of Archean age in various degrees of weathering. Charnockites and hornblende biotite gneiss show weak foliations. They are present as massifs and are medium grained. The southern part of the study area is highly weathered. The entire region consists of charnockite with a maximum of 
three sets of joints in varying degrees of weathering with a small patch/intrusion of garnet sillimanite cordierite gneiss with a limited soil cover. The elevation varies from 291 to $2346 \mathrm{~m}$, most slopes dip the western direction with their gradient ranging from $0^{\circ}$ to $65^{\circ}$.

The landscape primarily consists of structural hills. The northern tip is characterized by pediments and denudation hills, and the south-western tip with weathered hill top. Major portion of the study area are dessicated slopes. The southern part of the region is a moderately dessicated plateau. Commercial plantations like plums, peaches, butterfruit, etc., are the predominant land use category. Settlement density is very high in the southern part of study area. There are numerous hill streams cutting across the terrain.

\subsection{Debris flow characterization and inventory mapping}

Debris flows are usually induced by rainfall in this region and are characterized by small translational slides within the saturated, unconsolidated soil on the slope which gather momentum in the presence of water and travel down-slope as debris. The field survey carried out in the Palar subwatershed shows that debris flow occurred on hill slopes covered with relatively thin $(<2 \mathrm{~m})$ mostly unconsolidated and coarse-grained superficial deposits. The debris flows are hill slope (open type) debris flows (Cruden and Varnes 1996) forming their own path down the valley and depositing the material on the lower slopes with a lesser gradient.

The three fundamental conditions for the initiation of debris flow (Lorente et al. 2003; Shieh et al. 2009; Quan Luna et al. 2011; Okano et al. 2012) are:

(i) Abundance of loose material that includes soil, gravel, cobble and weathered rock or boulders;

(ii) Slope gradient that aids debris flow to surpass the threshold for debris flow initiation and progress;

(iii) Sufficient streamflow.

Observations from the field survey and inspection show that the debris flow events in Vilpatti, Kodaikkanal town and Kumburvayal consist of the loose solid particles in the form of accumulated weathered rock, gravel, small boulders and coarsegrained sand is present as unconsolidated material on the slope, ready to be moved by the drag of moving water at moderate speed and thrust. The

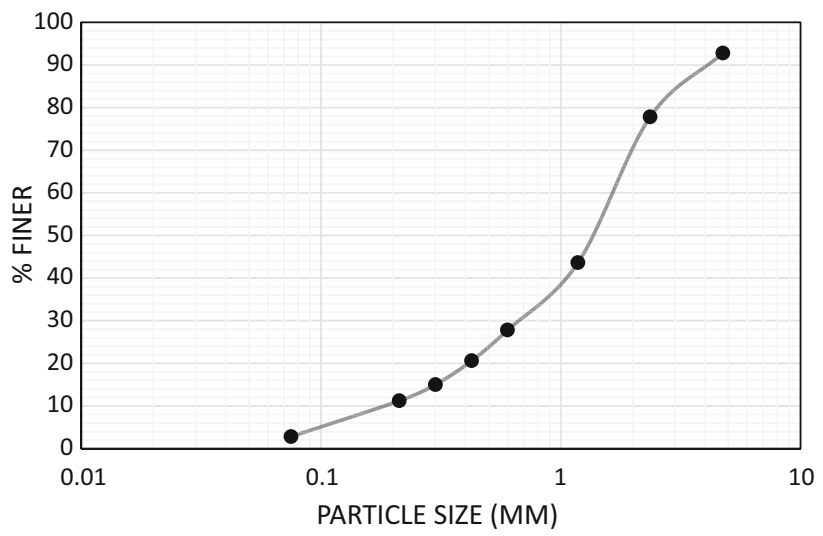

Figure 2. Representative particle size distribution curve of typical soils in Palar subwatershed.

slope gradient in this region is moderate to steep that aids in the debris flow process. The slopes provide sufficient momentum for the debris flow. Prolonged intense rainfall with saturated soil conditions alone stimulates debris flow in this region. Soil deposits on the slope are medium fine sand with clay binders (figure 2) and their hydraulic conductivity is moderate, allowing free drainage of water due to gravity vertically downward till the bedrock interface where the gradient of flow is abruptly reduced, thereby initiating movement of material parallel to the slope. Adding to it, rain feeds the numerous streams that cut across the slope.

Debris flow is caused by either washing the loose unconsolidated material into the streams or moving the material deposited in the streams down the slopes on a huge scale, gathering volume as it flows down the slope. The local residents report that most debris flow in the region is rapid and is accompanied with significant noise.

The soil and weathered material on the slope washed by debris flow are deposited down-slope. As the flow moves down along the slope, debris scree accumulates and causes the flow to lose momentum and this aids in deposition of material down the slope. In the 2009 and 2014 debris flow events, it was observed that significant flow of water was required to mobilize the debris and the slope gave away in places where there were collective water outlets. Commercial plantations like banana, plum, pear, peach, avocado, turnip, beans and butter beans are cultivated on the slopes. The shallow roots of these plants were found to be insufficient to hold the soil during the debris flow, resulting in the wash out of these gardens along with the loose debris material. The areas where these debris 
material deposited are rendered uncultivable. An example for this scenario is the valley in which the debris material of 2009 debris flow was deposited. After 7 years, it is still barren, devoid of cultivation. The debris flow events occur in isolation and are not generally reactivated in the recent past. But slopes in the vicinity of the failed slopes are affected during the subsequent monsoon season.

A debris flow inventory map is prepared from field survey, aerial photographs and satellite imagery. It shows the location of perceptible debris flow and identifies definite and probable locations of existing landslides (Yilmaz 2009). It helps in understanding the conditions stimulating debris flow events. Debris flow events between the period of 2006 and 2014 are considered for the study. In this study, locations of 22 debris flow source areas are identified and are used to build the ANP model. These incidences date between 2006 and 2013. They are used to construct the pair-wise comparison matrix and subsequently arrive at the global priorities which are used as weights to map the debris flow susceptibility. Seven debris flow incidences that occurred in 2014 are used to validate the debris flow susceptibility map generated by the ANP model. Debris flow locations are incorporated in the thematic factor maps (figures 3, 4, 6, 7 and 8).

\subsection{Spatial database of debris flow conditioning factors}

Debris flow is a special category of mass movement where the predisposing factors setting the stage for the event are the availability of materials, type of materials, stream power, slope gradient, aspect and curvature, lithology, land use and land cover, lineament density, drainage, etc. (Carrara et al. 2008; Hürlimann et al. 2008; Iverson et al. 2010; Liang et al. 2012; Meyer et al. 2014). Rainfall is the triggering factor that stimulates debris flow events in this region as there is very limited seismic activity and the region falls under moderate seismic zone. A study on the local geo-environment based on various sources like topographic maps, satellite images and information collected from field survey and a comparison with debris incidence in this watershed emphasizes that the factors influencing debris flow susceptibility in this region are the (i) availability of material on the slope, (ii) peak flow, (iii) gradient of the slope, (iv) land use and land cover change and (v) proximity to streams. Though rainfall also affects debris flow occurrences, the region has inadequate rainfall data and the two rainfall stations are just $3 \mathrm{~km}$ apart from each other located in the southern part of the study area. Field observations and literature show that there is limited spatial variability of rainfall and hence it is not considered to map debris flow susceptibility.

\subsubsection{Availability of materials}

The vulnerability of materials to mobilize into a debris flow is sensitive to the gradation of slope materials (Gabet and Mudd 2006). Granular soil like sand is more prone to liquefaction than clay on account of their high hydraulic conductivity (McMillan et al. 2005) and their potential to mobilize into a debris flow is much greater if the distribution of particle size varies over an extensive range. Field survey and inspection show that the materials in most micro-watersheds, which are commonly assumed to be homogenous in their hydrologic response to land cover change, are granular in nature with very less or no cohesion. Sixty soil samples were collected from the entire Palar watershed, particle size analysis and textural classification was used to categorize the soil. The soil in the region falls under three types - sandy loam, sandy clay loam and sandy clay. The gradation of the debris material ranges from small-sized boulders, pebbles/cobbles (rounded to sub-rounded in shape), gravel (flaky) coarse sand to fine sand less than 150 microns. Mostly, the particles are smooth, enabling the material on the slopes to be very easily mobilized by water. The quantity of slope material available depends on the lithology, curvature of slope and thickness of the overburden. The superficial deposits are predominantly medium fine sand with $2.8 \%$ fines in the soil matrix with a weathered material of larger size. The average effective size of the soil samples collected from various slopes is $0.2 \mathrm{~mm}$ and a representative particle size distribution curve of the soil (figure 2) shows that $57.2 \%$ of the soil falls in the medium coarse category and $15 \%$ in the coarse and $17.8 \%$ in the fine sand category. The field unit weight was determined in the field at the points where soil samples were collected using core cutter. It reflects the packing of the soil in the field and on average is $13 \mathrm{kN} / \mathrm{m}^{3}$, typical of granular soil indicating that the soil is susceptible to movement downslope. Lithology, particularly rock type and mechanical behaviour also controls the quality and quantity of material available on the slope (Tang et al. 2009), but the bedrock geology in the entire region is mostly monotonous 


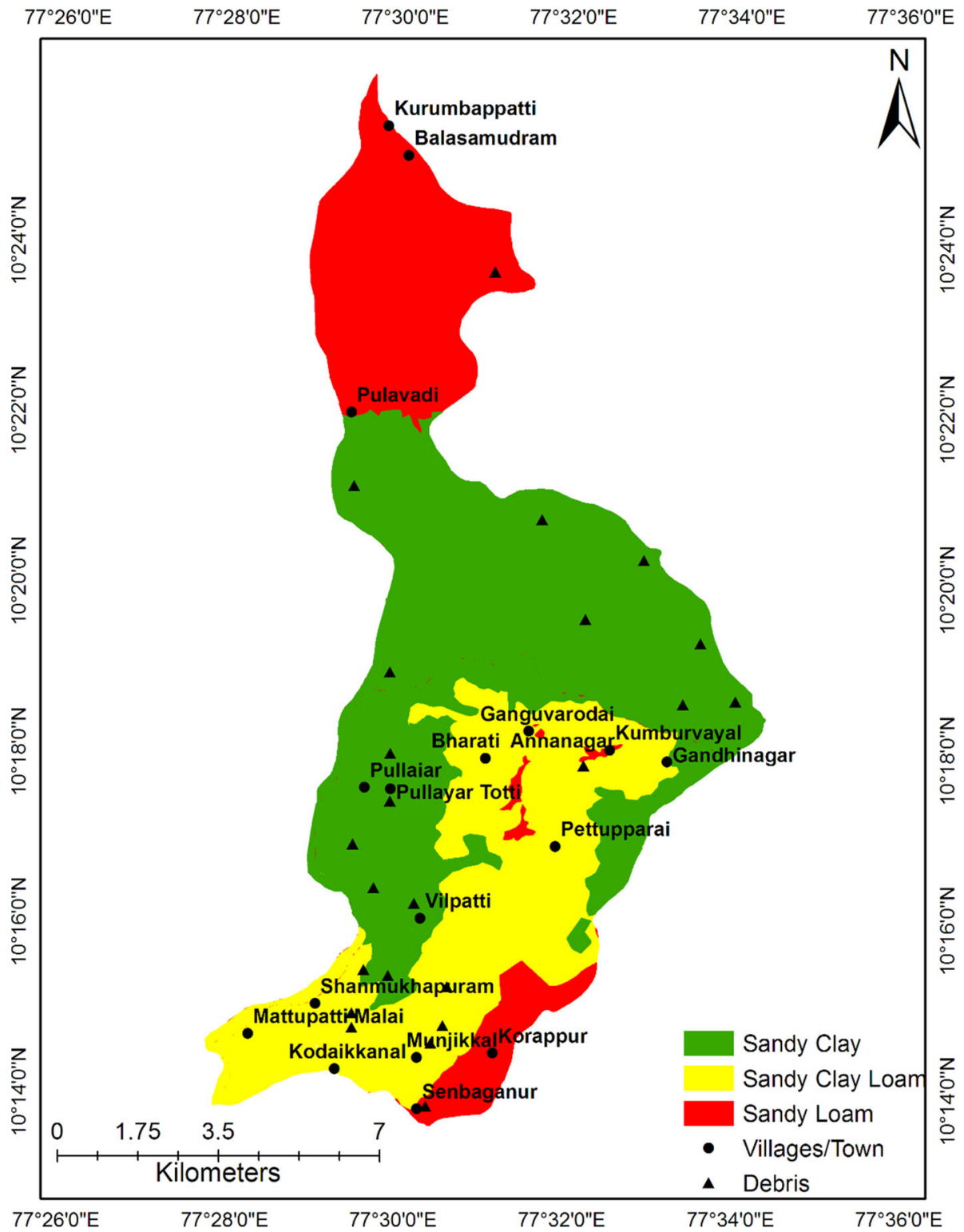

Figure 3. Spatial distribution of availability of material for debris flow on the slopes of major soil types in the Palar subwatershed.

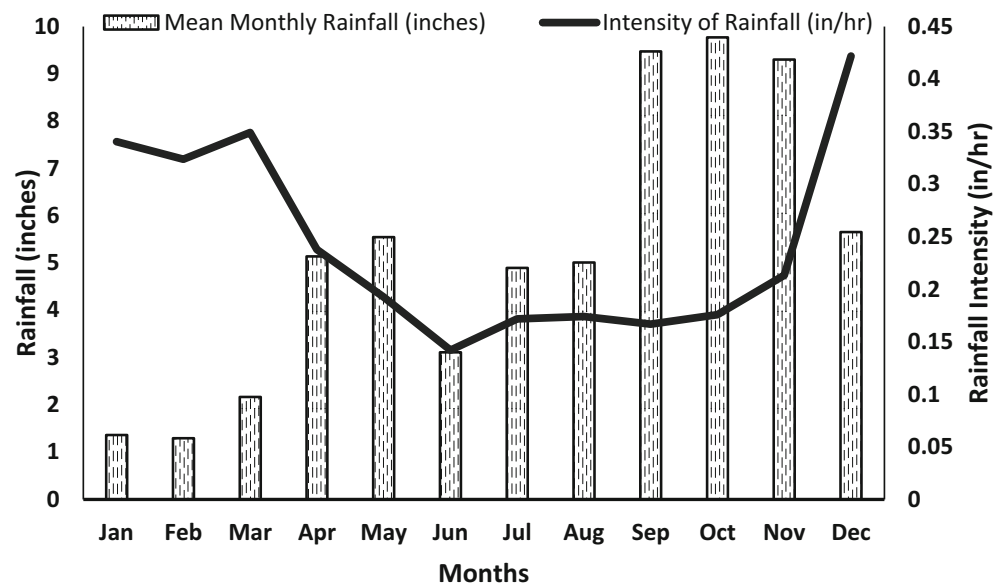

Figure 4. Monthly rainfall climatology and rainfall intensity in the Palar subwatershed. 
and hence the degree of weathering dictates the availability of weathered material. Figure 3 shows the spatial variation of the availability of material with a potential to cause debris flow. The thickness of the superficial materials on the slopes vary from nearly bare slopes with no soil or weathered material cover to a maximum of $3-5 \mathrm{~m}$ thick regolith.

\subsubsection{Peak discharge}

The peak discharge $\left(Q_{p}\right)$ and the magnitude of surface runoff in the watershed are of essential consequence to the mobilization of debris flow. Higher the magnitude of flow, greater is their potential to carry higher sediment load and, therefore, higher the susceptibility for chances of a debris flow. The subwatershed is divided into micro-watersheds, a basic computational spatial unit with similar soil, land use and slope, assumed to be homogenous in hydrologic response to land cover change (Arnold et al. 2012). This is done using the Soil Water Analysis Tool interface in ArcGIS (SWAT, Arnold et al. 2012). The rational method is used to calculate the peak flow in each micro-watershed. The choice of this method to calculate the peak discharge is attributed to its simplicity and reflection of watershed conditions. The equation for the same is given below:

$$
Q_{p}=C i A,
$$

where $Q_{p}$ is in $\mathrm{ft}^{3} / \mathrm{s}, C$ is the runoff coefficient, $i$ is the intensity of rainfall in inches/hr and $A$ is the area of the micro-watersheds in acres.

The runoff coefficient $C$ depends on the hydrological classification of the soil, the slope and the land use of the micro-watershed. In this case, the soil of the entire Palar subwatershed falls under the hydrological soil group ' $\mathrm{B}$ ' which is silt loam or loam. This classification is based on the soil's run-off potential (Brakensiek and Rawls 1983). The slope map was prepared from ASTERDEM and the land use map from LANDSAT image for the year 2014. These maps were used to extract the slope and land use for each micro-watershed. The intensity of rainfall is calculated from the climatological data between 1971 and 2000 published by Indian Meteorological Division, Chennai. Figure 4 depicts the variation of rainfall in the pre-monsoon, monsoon and winter months. The intensity of rainfall is calculated to be 0.242 inches $/ \mathrm{hr}(0.61 \mathrm{~cm} / \mathrm{hr})$. The peak discharge in the micro-watersheds varies from 36 to $107 \mathrm{ft}^{3} / \mathrm{s}\left(1-3 \mathrm{~m}^{3} / \mathrm{s}\right)$. The peak discharge is reclassified into three categories as low, moderate and high based on natural breaks classification. Figure 5 shows the reclassified peak discharge map used as input for mapping debris flow susceptibility.

\subsubsection{Slope gradient}

Slope adversely affects the susceptibility of the region to the occurrence of debris flow. Steeper the slope angle, greater is the potential of the slopes to fail and, in this case, initiate debris flow as the shearing resistance of the superficial materials reduces causing failure. Slope map was derived from ASTER DEM using the spatial analyst extension of ArcMap. The natural slope angle in the subwatershed range from $0^{\circ}$ to $66^{\circ}$ with a mean slope of $19^{\circ}$ but along the road cuts, steeper slopes have been made to nearly $80^{\circ}$. The study has used only natural slope angles as the cut-slope angles are discrete, i.e., only along the road stretches. Slope angles have been classified into three categories - gentle $\left(0^{\circ}-15^{\circ}\right)$, moderate $\left(15^{\circ}-35^{\circ}\right)$ and steep $\left(>35^{\circ}\right)$. Figure 6 shows the spatial distribution of slope angle in the micro-watersheds. It is observed that the predominant slope angle falls in the categories $15^{\circ}$ and $35^{\circ}$ making the watersheds highly susceptible to debris flow. A considerable portion also falls in the gentle slope angle category too.

\subsubsection{Land use and land cover}

Vegetation cover on the slopes can both aid and affect the stability of the slopes. The study area is affected by shallow landslides and debris flow, which are surficial mass-movements and hence the presence of vegetation can act as a barrier to debris flow event. The vegetative cover reduces the infiltration of rain water into the superficial slope materials depending upon the type of vegetation. The roots act as an interlocking network preventing the erosion or removal of material by providing a root reinforcement, again depending on the type of vegetative cover. Hydrological factors like moisture control on slope material due to evapotranspiration or increase in moisture due to additional irrigation for commercial cultivation, surcharge weight of the forests (depending on the steepness of the slopes) and wind-breaking effect of trees can aid in either increasing or reducing the stability of slopes. Urban or rural development is also critical for the debris flow initiation owing to the inappropriate removal of surface water, saturating a susceptible slope, increasing the antecedent water level prior to 


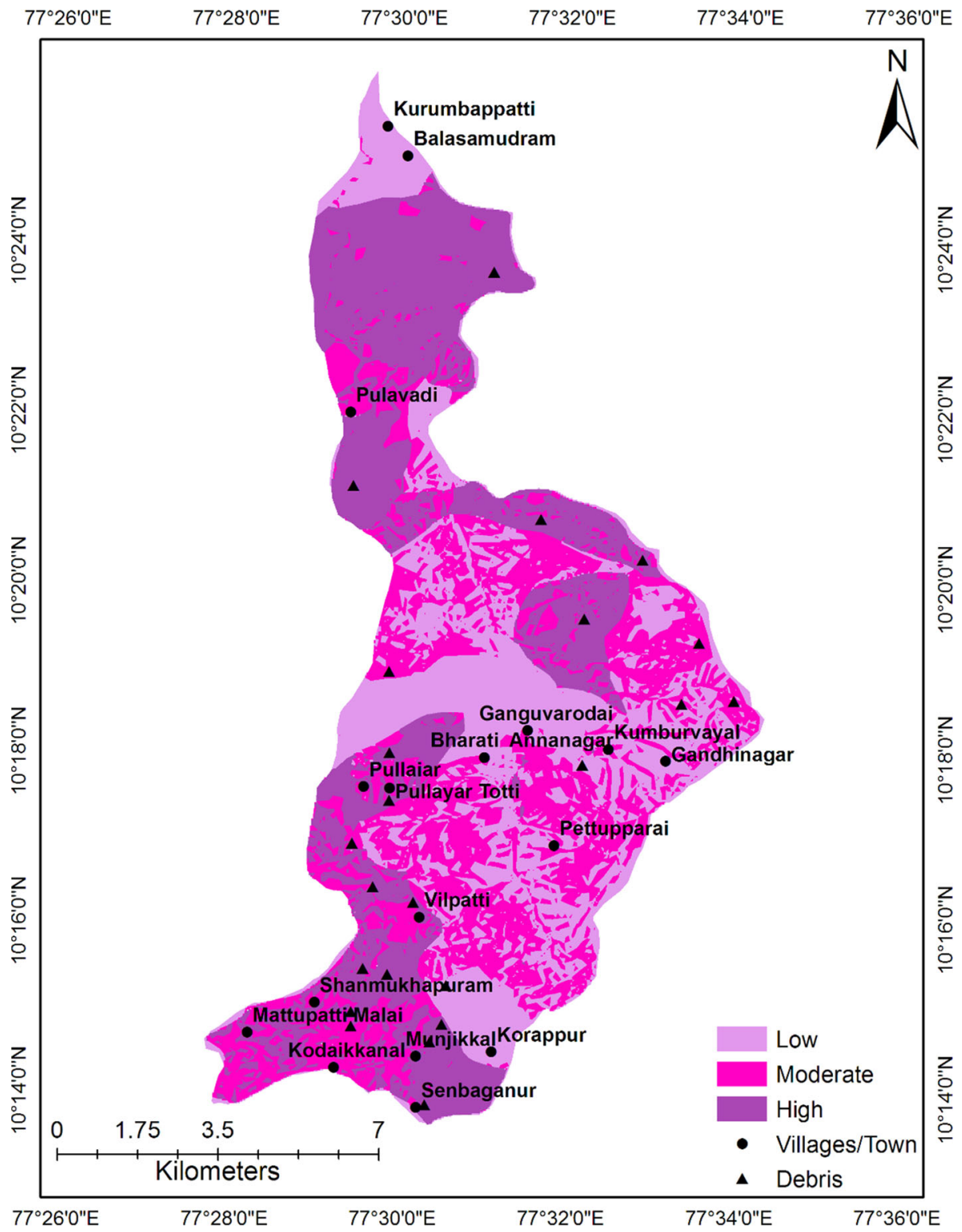

Figure 5. Spatial variation of peak discharges categorized into low, moderate and high flows in the Palar subwatershed.

the initiation of a debris flow event (Winter 2013) or can be the major cause of the initiation of the debris flow event (as in the case of 2014 debris flow event), providing an additional impetus to the existing momentum of the rain-water. The land use map was prepared from the LANDSAT 8 satellite image at $30 \mathrm{~m}$ resolution (dated 5 May 2014 of $30 \times 30 \mathrm{~m}$ spatial resolution; Path: 143; Row: 53). The land use and land cover data in the selected micro-watersheds is reclassified into forests, plantations and settlements (figure 7).

\subsubsection{Proximity to streams}

Streams have a close association to debris flow occurrences as they provide not only the path for the flow of water and debris material during the event but also are a major source of water supply that is used to mobilize the available material on the slopes. At times of moderate flow, they aid in collecting material that form debris dams (Winter 2013). Numerous hill streams cutting across the slopes act as chief agents of erosion and hence key factor in deciding the susceptibility of a catchment to debris flow susceptibility. Areas adjacent to the streams are more susceptible to probable debris flow, particularly at the confluence. Drainage map was derived from the topographic map of 1:25000 scale and is used to generate the buffer map. Buffer analysis is carried out using spatial analyst extension in ArcMap. The buffer distances selected for the study are: $<100 \mathrm{~m}, 100$ $500 \mathrm{~m}$ and $>500 \mathrm{~m}$ from the stream to account for 


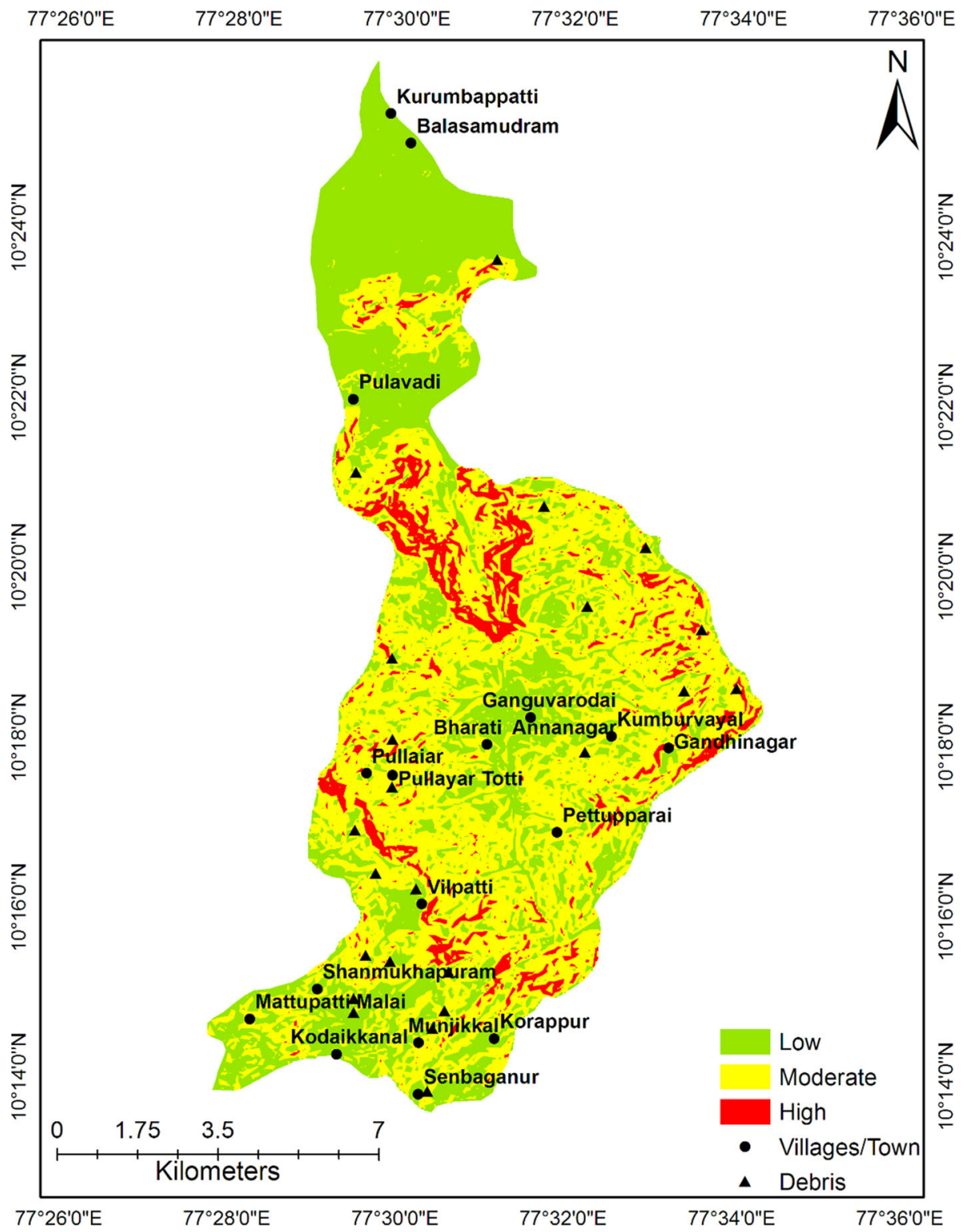

Figure 6. Spatial distribution of low, moderate and high slopes with steep areas concentrated in the central regions of the subwatershed.

the susceptibility owing to proximity of streams. Figure 8 portrays the buffer analysis used for the study.

\subsection{Analytical network process}

Analytical Network Process (ANP) model is used to rank and assess the influence of the selected parameters on debris flow hazard using the scores or weights called 'priorities'. The scores or the priorities are used for spatial mapping of the zones susceptible to debris flow hazard and the susceptibility map genereated is validated by site-specific inspection.
ANP is a multi-criteria, decision-making method (Saaty 1999) and is a generalization of Analytical Hierarchical Process (AHP), which reduces the complex problem to a non-linear network which is in itself a linear hierarchical structure (Saaty 1999; Saaty and Vargas 2006; Bottero et al. 2011). It thus includes the application of AHP to interdependent relationships in the evaluation of elements and generalizes the process of super-matrices introduced by AHP. ANP is an efficient tool that can handle decision-making issues that are not structured hierarchically, i.e., interaction and dependencies exist between the highest and the lowest elements (Saaty 1999; Saaty and Vargas 2006). Saaty (1999) thus represented these complex real time problems 


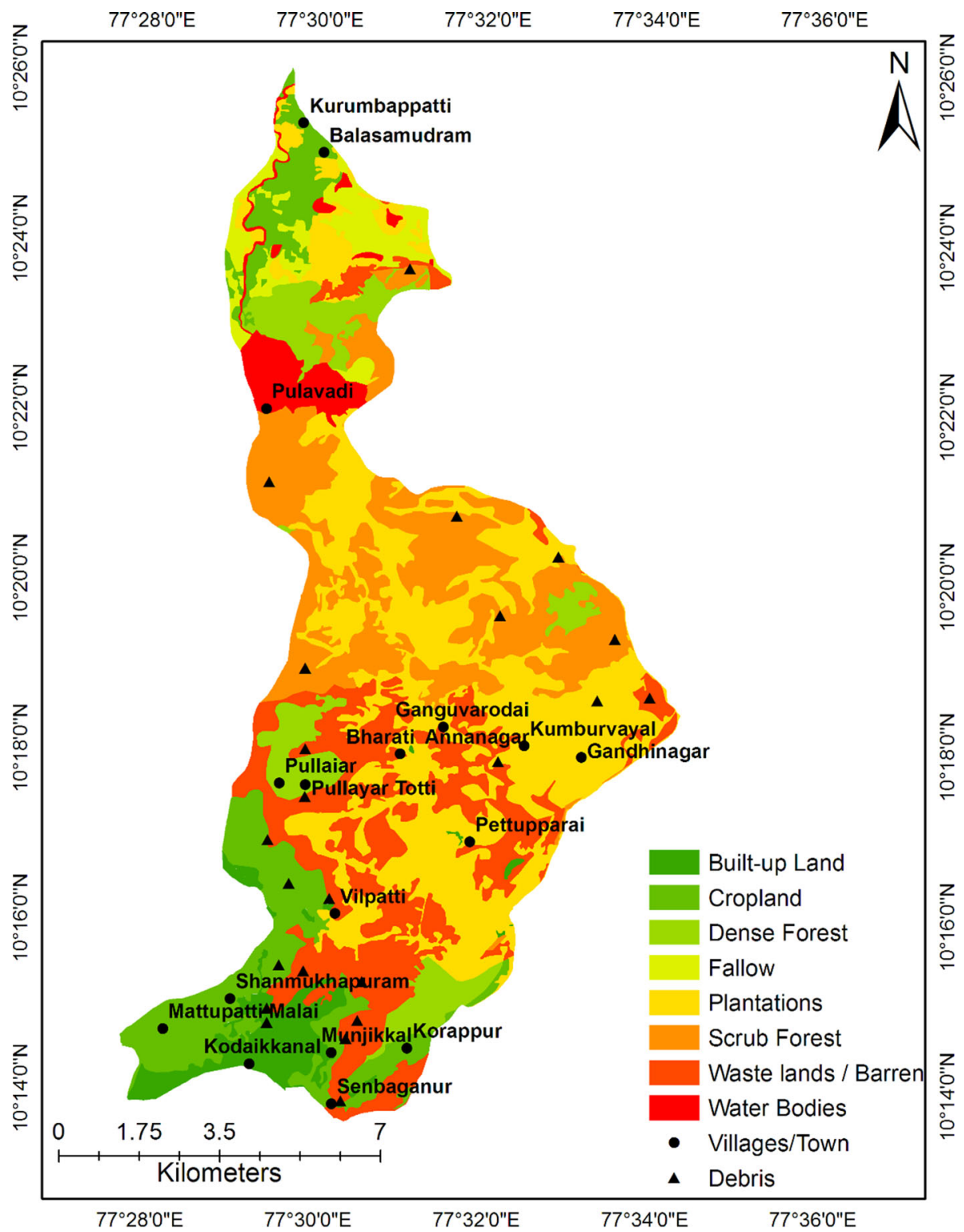

Figure 7. Land cover and land use classification representing eight classes in the Palar subwatershed.

as a network of criteria and alternatives that are grouped into clusters. All the elements can be associated in any prospective way, through feedbacks and inter-relationships within and between the clusters (Bottero et al. 2011). ANP thus empowers to investigate and quantify the inter-dependencies. This dependency and interaction affect the importance of the criteria as well as the alternatives both ways. ANP demands a network structure and a pair-wise comparison to institute the relationships within the structure, to represent the decision issue to be modelled. Every ANP model incorporates three basic clusters which are - goal, criteria and alternatives. An ANP model is divided into four phases: (i) structure of the decision network, (ii) pair-wise comparison, (iii) construction of super-matrix, and (iv) global priorities.

The network model is constructed based on the objective, and is divided into groups called clusters that consists of elements called nodes and alternatives (figure 9). The relationship between nodes within and outside the clusters are identified. The network can either be a simplex or a complex network. This study uses a simple network, i.e., a network structure not supported by any pre-determined structure. The pairwise comparison judgments are made using the fundamental scale of the AHP and the judgements are arranged in a matrix, the pairwise comparison matrix. The priorities of an AHP pairwise comparison matrix are 


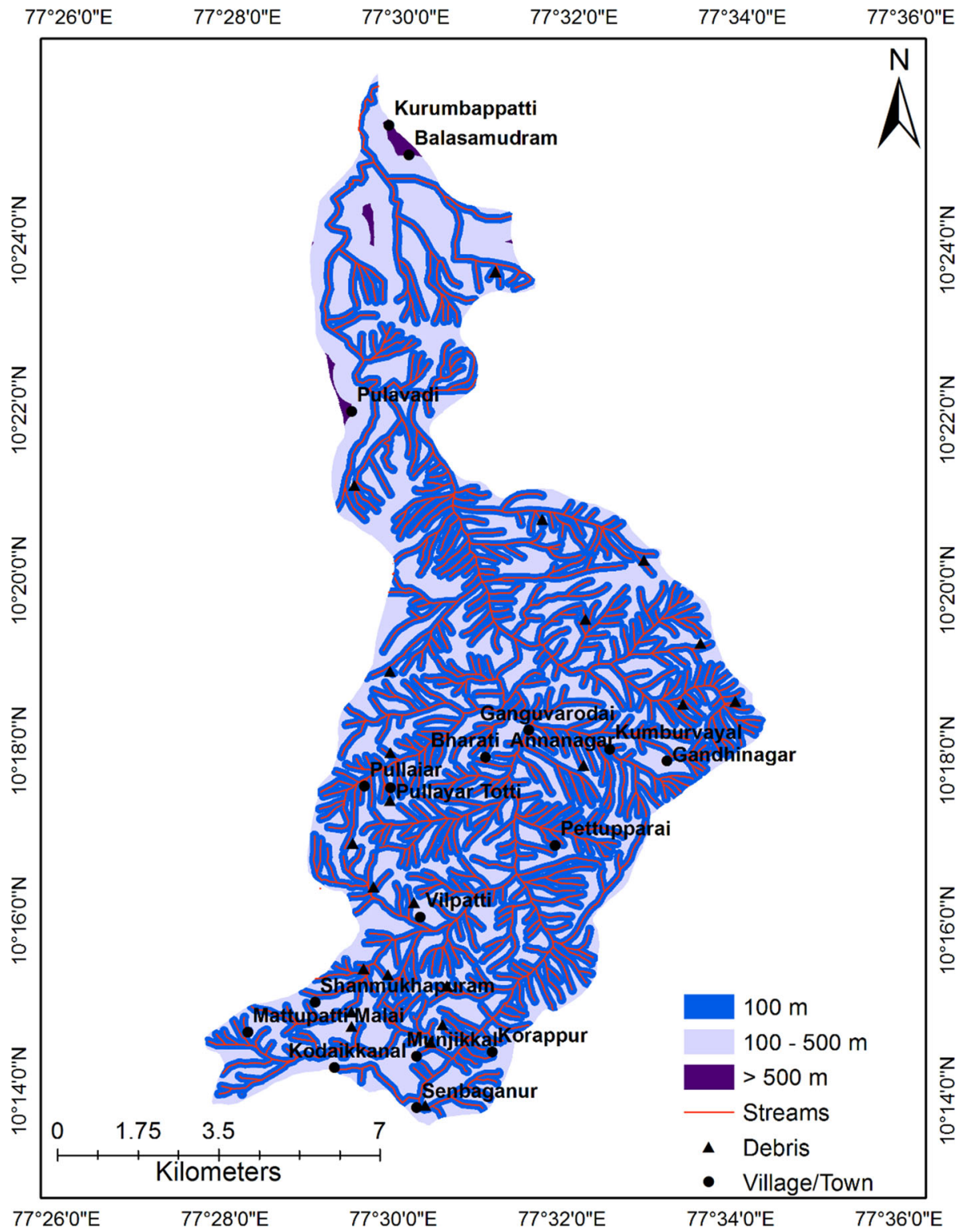

Figure 8. Stream buffer width classification and the proximity categories of debris flow to streams.

obtained by solving for the principal eigenvector of the matrix. The mathematical equation for the principal eigenvector $w$ and principal eigenvalue $\lambda_{\max }$ of a matrix $A$ is given below. Matrices have more than one eigenvector; the principal eigenvector which is associated with the principal eigenvalue $\lambda_{\max }$ (i.e., the largest eigenvalue) of $A$ is the solution vector used for an AHP pairwise comparison matrix (Saaty and Saaty 2003).

$$
A_{w}=\lambda_{\max } A
$$

The paired comparisons are used to create a supermatrix and is used to assess the priorities based on the interdependencies that exist in the elements of the network (Saaty 2005). The initial or the unweighted super-matrix consists of several eigenvectors, the sum of which is equal to one (Neaupane and Piantanakulchai 2006). It contains the local priority vectors of the comparison groups in the network. The elements in the super-matrix are zero when the elements in the network are not dependent but ranges between one and zero if interdependency exists. The unweighted super-matrix is converted to a matrix in which each of the columns sums to unity called the weighted super-matrix and is obtained by multiplying each node in the cluster of the unweighted super-matrix by the weight of the cluster (Saaty 2001). The weighted supermatrix is then raised to powers until it converges 


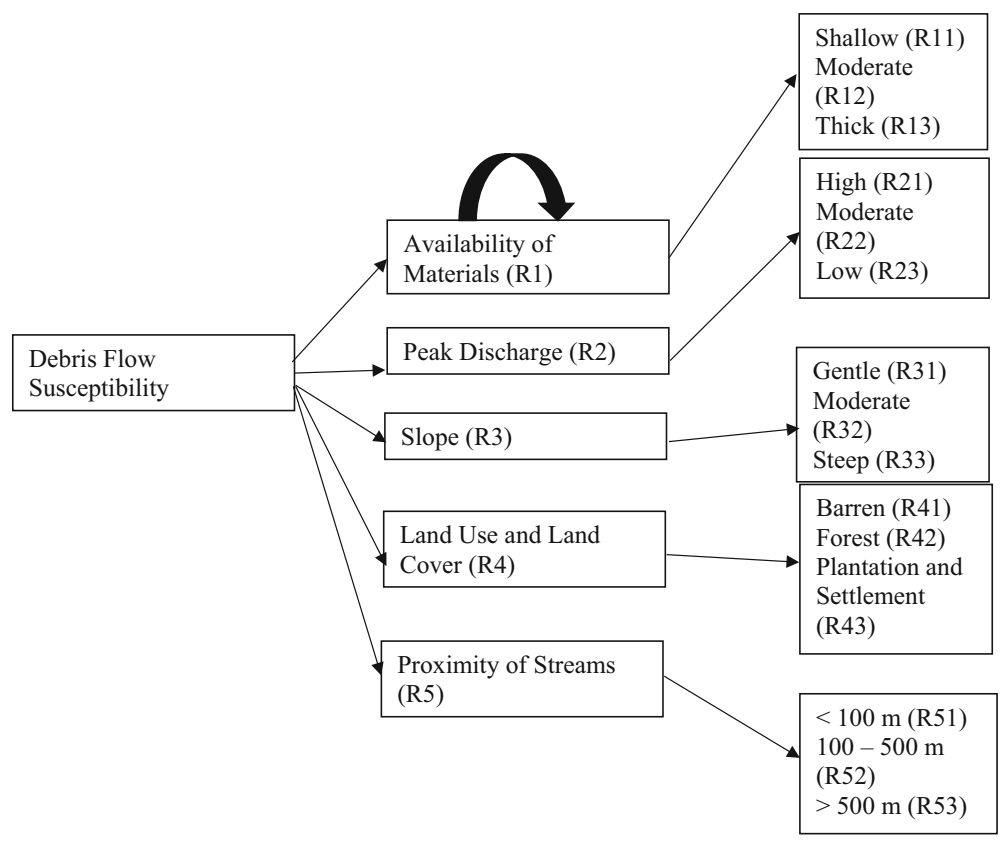

Figure 9. ANP model showing the interdependent factors to assess debris flow susceptibility.

to all the columns in the super-matrix that have the same value. This super-matrix is called the limit super-matrix and contains the priorities of the alternatives and other elements in the model (Saaty 2001). Calculus type algorithm is used in the Super Decisions Software to facilitate the formation of the limit super-matrix and calculation of priorities (Zhen et al. 2005).

The ANP model generated for the study with interaction is depicted in the figure 9 . The working of the ANP model is as follows. An analytical network process model with the clusters debris flow susceptibility (goal), factors affecting (criteria) and the different categories within each factor (alternatives) is created. Factors causing debris flow can be treated as independent of each other or dependent on each other. ANP uses interaction to model the inter-dependency between the factors. In this study, availability of material, slope gradient and land use are considered to be inter-dependent. A pair-wise comparison matrix is constructed based on the debris flow incidences to define the relation between each criteria and alternative. The pair-wise comparison matrices are used to generate the super-matrix, from which global priorities are obtained. These global priorities reflect the importance of each factor in causing debris flow. These global priorities are used as weights to assess debris flow susceptibility.

\section{Results}

\subsection{Debris flow susceptibility map}

The factors causing debris flow - availability of material (R1), peak discharge (R2), slope (R3), land use (R4) and proximity to drainage (R5) are combined in ArcGIS environment to generate the debris flow susceptibility map. The weights assigned to the factors are based on the global priorities obtained from the ANP model (with and without interaction between the parameters). The weights (global priorities) are shown in figure 10 . The case of weights with interaction is used for the analysis.

The algebraic sum of the weights for the factors is used to assess the debris flow susceptibility (DFS).

$$
\mathrm{DFS}=\sum \text { Global Priorities }
$$

The debris flow susceptibility map thus generated is reclassified into three categories - low, moderate and high. The map shows that there is a significant spread of high hazard zones in the southern and northern part of the study area (figure 12). The high susceptibility regions include Kodaikkhanal town (Senbagur, Munjikal, Shanmukhapuram) and follows the downward trend with wider patches on the western side covering villages like Vilpatti and 


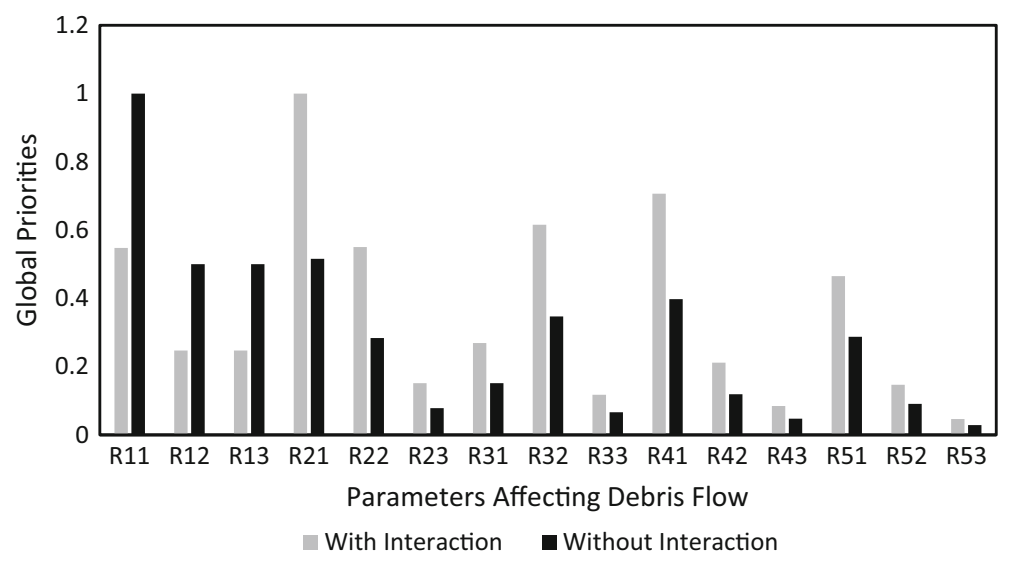

Figure 10. Effect of interaction between the sub-factors causing debris flow on global priorities (weights).

Pullaiyar Totti, where there are aggressive terrace cultivation and the eastern side which houses plantations and orchards. In the northern part, Pulivadi and the plantations fall under the high hazard category. It is observed that nearly $41 \%$ of the Palar subwatershed is not susceptible to debris flow and $33 \%$ fall in the high susceptibility category.

\subsection{Validation}

The validation of the debris flow susceptibility map generated using ANP model is carried out with the help of $R$ index that correlates the relationship between debris flow inventory and susceptibility using spatial autocorrelation to measure the degree of fit between the debris flow incidences and the susceptibility map (Baeza and Corominas 2001; Sujatha and Rajamanickam 2011). The validation model intends to evaluate the quality of the susceptibility map generated as a predictive tool to elucidate the debris flow incidences in the selected subwatershed. In this study, $R$ index (Baeza and Corominas 2001) measures the degree of fit between the debris flow validation dataset (which includes the debris flow that occurred during the heavy monsoon rainfall in the year 2014, i.e., a temporal dataset) and the susceptibility map generated using ANP model. $R$ index used to assess the debris flow susceptibility map is calculated as:

$$
R \text { index }=\left[\left(n_{i} / N_{i}\right) / \sum\left(n_{i} / N_{i}\right)\right] * 100,
$$

where $n_{i}$ is the number of debris in the susceptibility level ' $i$ ' and $N_{i}$ is the area occupied by the cells of susceptibility level ' $i$ '.

Table 1 represents the $R$ index for the susceptibility levels demonstrated in the map and it represents the percentage of area affected by the debris flow in each susceptibility category. The susceptibility map is deemed to be of higher quality if fewer debris flow incidences fall in the low susceptibility categories (relative error), i.e., lesser area is affected by debris flow in and more debris flow incidences fall in the high and very high susceptibility categories (relative accuracy) (Fernandez Merodo et al. 2004; Irigaray et al. 2007). When this given level of quality is achieved, the susceptibility map generated is considered satisfactory to be used as a predictive tool in explaining the future occurrences of debris flow. Table 1 shows that $R$ index increases with the susceptibility class. This indicates that the quality of the model generated using ANP is acceptable as a predictive tool for mapping debris flow susceptibility.

\section{Discussion}

The study shows that analytical network process model is an efficient tool to help model natural hazards like debris flow, particularly when the data is scarce. It has paved a way to combine heuristic judgments and field observations to supplement limited data availability and has helped to develop a robust debris flow susceptibility model, yielding quantitative results in the form of global priorities. A heuristic model is constructed based on the limited debris flow incidences. The factors causing debris flow are not truly independent of each other. This model has taken into account the interdependcy, i.e., interaction between the factors. This is a unique advantage of using this model. The model treats the subcategories of each factor as separate entities (figure 10) and derives their 
Table 1. Validation of debris flow susceptibility map using $R$ index.

\begin{tabular}{lccr}
\hline $\begin{array}{l}\text { Susceptibility } \\
\text { class }\end{array}$ & No. of pixels & No. of debris & $R$ index \\
\hline Low & 52,317 & 3 & 31.77 \\
Moderate & 58,432 & 8 & 75.86 \\
High & 16,687 & 12 & 398.44 \\
\hline
\end{tabular}

impact in terms of global priorities. They are the scores/weights assigned to each subcategory.

\subsection{Interaction effects and the advantages of analytical network process (ANP)}

The unique advantage of using ANP is the option to use feedback and interaction between the elements. The parameters used to model debris flow are not mutually independent. For example, the slope gradient and land use pattern have a profound effect on the material available on the slope. This interdependence of the selected factors can be modelled using ANP. The analysis is carried out with and without interaction between the parameters. A comparison of global priorities with and without interaction between the factors is presented in figure 10.

Figures 10 and 11 show that there are significant changes in the priorities of the factors that contribute to debris flow, particularly this is evident in the case of availability of material and peak discharge. The model that considers the interaction between the factors indicate that peak discharge has a higher weight than the availability of material on slopes. Though the difference in magnitude of the weights is not very significant, it brings out the fact that peak discharge is an important factor in mobilizing debris flow. Again, only a slight difference in magnitude of weights of these factors underline the interdependency of these factors in causing a debris flow event.

Importance of interaction is seen in case of slope, land use and proximity to drainage but influence of interaction is relatively lesser on these parameters. No change is observed in the case of steep slopes, forested areas and no proximity to drainage.

\subsection{Inferences on debris flow factors}

The results of the model show that peak discharge in the micro-watersheds is the most important factor causing debris flow followed by the availability of the material when the interaction between the

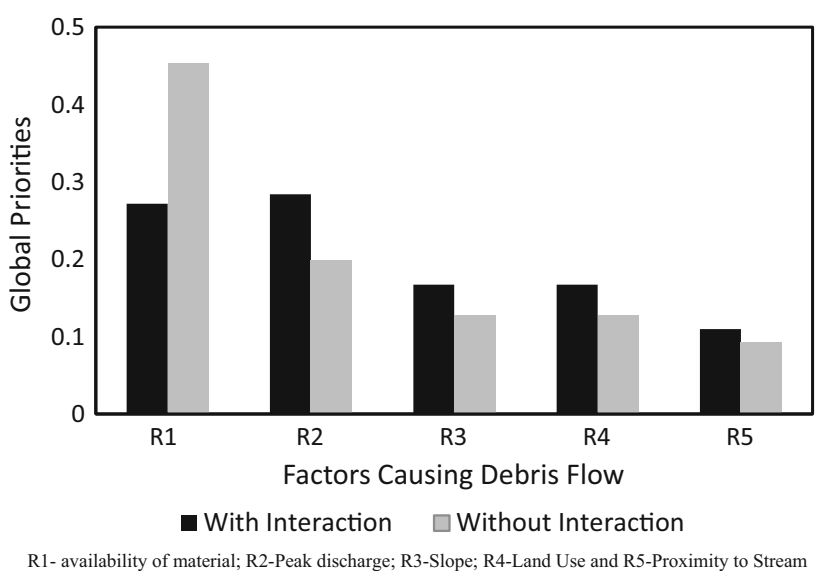

Figure 11. Effect of interaction for five factors causing debris flow.

factors is taken into account. But if the interaction is not taken into account, the availability of debris material is the single most important factor that causes debris flow (figure 11). The results of the study show that microwatersheds with high peak discharge are more susceptible to debris flow. Nearly $74 \%$ of the debris flow events occur in the micro-watersheds with high peak flow. This shows that interaction between the parameters must definitely be taken into account for simulating near field conditions for the model.

Second most important factor that contributes to debris flow is the availability of material. The granular and weathered material on the slopes are readily moved down in the presence of water (Winter 2013). The study points out that larger volume of material, a combination of the higher thickness of soil cover and abundant weathered rock scree have very high potential to be washed along the slope. But moderate and low material availability in the form of granular material with a small amount of weathered rock has equal chances of being carried down the slopes. It can be inferred that both quality and quantity of material are important for the mobilization and downward movement. Sandy loam is more susceptible to debris flow.

Land use and slope play significant role in initiating a debris flow event (Fell et al. 2008; Hürlimann 


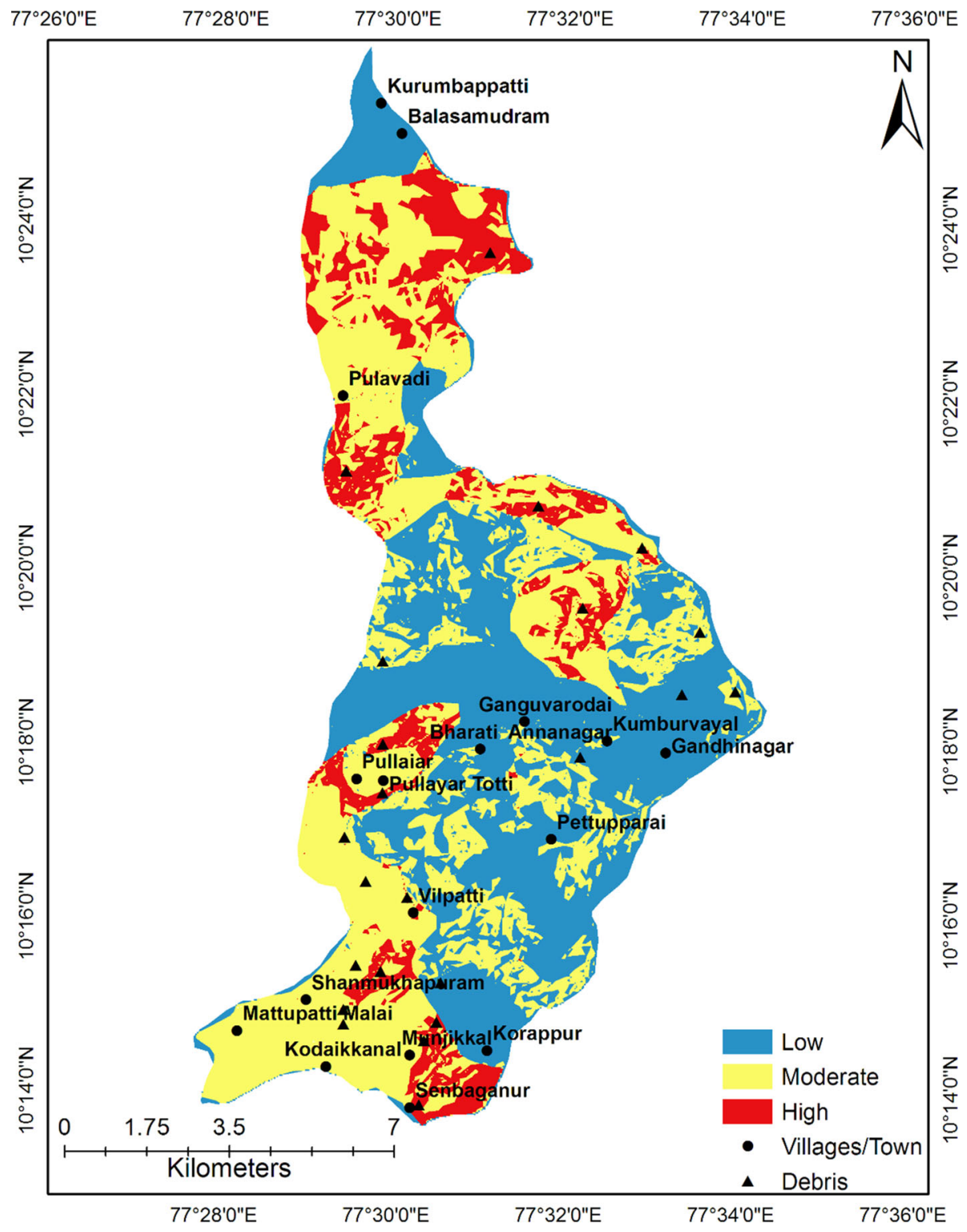

Figure 12. Debris flow susceptibility map of the Palar subwatershed.

et al. 2008) (figures 10 and 11). Debris flow frequently occur in waste lands covered with scrub. This can be attributed to the minimum root support provided by scrubs in holding the soil during a debris flow. Plantations and orchards are also susceptible to debris flow. This can be attributed to the shallow root system and less root cohesion of the trees or crops cultivated and unhealthy irrigation practices, particularly, in regions where vegetables like carrot, potato, beans, turnips, etc., are grown. Forests are a deterrent to flow events and evidence of such events are very rare in forested areas. Evidence points to the fact that anthropogenic disturbance is a major cause in stimulating a debris flow event as modified slopes with alternative vegetative cover are more susceptible in general. Field surveys indicate that unhealthy irrigation practices saturate the slopes and increase their weight, causing them to fail during intense precipitation. Also, slopes are cut into terraces for cultivation, which serves to prolong the time water remains on the slopes.

Slopes with gradients between $15^{\circ}$ and $35^{\circ}$ are moderately steep and retain a major portion of the superficial material and has the greatest potential to initiate a debris flow event. Hence, slopes in the range of $15^{\circ}-35^{\circ}$ are found to be more susceptible to landslides. Slopes that are steeper than $35^{\circ}$ and gentler than $15^{\circ}$ are observed to be less susceptible to debris flow (figure 12). Gentle slopes do not provide the impetus for a flow with large sediment loads of varying sizes, 
while steep slopes have neither colluvium nor soil can stand on these slopes (Magliulo et al. 2008; Meyer et al. 2014) and they are made of resistant bedrock. They also usually have lesser anthropogenic activities thereby remaining relatively undisturbed. But on a very steep slope $\left(>35^{\circ}\right)$, the materials have already moved down slope due to gravity, making the available regolith very less in quantum and thereby, these very steep slopes do not fall under the highly susceptible slope category. Steeper slopes are also suggestive of materials with greater strength (Meyer et al. 2014).

Another interesting fact that is observed in the study is that less number of debris occurrences are noted in the areas very near to the stream, while a higher number of occurrences happen far from the stream. This observation indicates that peak discharge is more influential in causing debris flow than the proximity to streams.

\section{Conclusions}

Debris flow causes significant economic losses in the Palar subwatershed annually. It has also resulted in severe injuries and property damage, particularly in residential areas. In this hill town of Kodaikkanal, inadequate data on slope failure restricts the use of probabilistic or statistical models. This provides the opportunity to employ heuristic methods to study slope failures and evaluate the factors associated with debris flow. One of the least explored heuristic methods known as the analytical network process (ANP) is used to map the spatial propensity of debris flow. The study points to the following conclusions.

- Analytical network process was appropriate to map the susceptibility of a natural hazard like debris flow with limited data. It has also identified the most influential factors causing debris flow and helped in ranking the factors influencing debris flow.

- The model efficiently brings into play the effectiveness of taking into account the interaction between the factors causing debris flow susceptibility instead of treating them as independent variables.

- The validation of the debris flow susceptibility map generated shows that distribution of debris flow is consistent with the susceptibility levels.

- The study has identified the basic unit, i.e., micro-watersheds that can be used to further explore the mitigation and control measures at a detailed scale. The use of micro-watersheds ensures that the susceptibility map caters to the micro-level mapping which can be very effective for local level planning and land management.

\section{Acknowledgements}

We would like to thank the Vice Chancellor, SASTRA University and Virginia Tech for facilitating the collaboration. We acknowledge Kumar Mallikarjunan for providing the opportunity and Mirz Billah for GIS modeling at Virginia Tech.

\section{References}

Aleotti P and Chowdhury R 1999 Landslide hazard assessment: Summary, review and new perspectives; Bull. Eng. Geol. Environ. 58(1) 21-44.

Althuwaynee O F, Pradhan B and Ahmad N 2015 Estimation of rainfall threshold and its use in landslide hazard mapping of Kuala Lumpur metropolitan and surrounding areas; Landslides 12(5) 861-875.

Arnold J G, Moriasi D N, Gassman P W, Abbaspour K C, White M J, Srinivasan R, Santhi C, Harmel R D, van Griensven A, Van Liew M W, Kannan N and Jha M K 2012 SWAT: Model use, calibration, and validation; Trans. ASABE 55(4) 1491-1508.

Baeza C and Corominas J 2001 Assessment of shallow landslide susceptibility by means of multivariate statistical techniques; Earth Surf. Process. Landf. 26 1251-1263.

Bhaskar Rao Y J, Chetty T R K, Janardhan A S and Gopalan K 1996 Sm-Nd and Rb-Sr ages and P-T history of the Archean-Sittampundi and Bhavani layered meta-anorthosite complexes in Cauvery shear zone, south India - evidence for Neoproterozoic reworking of Archean crust; Contrib. Mineral. Petrol. 125(2-3) 237-250.

Bhaskar Rao Y J, Janardhan A S, Vijaya Kumar T, Narayana B L, Dayal A M, Taylor P N and Chetty T R K 2003 Sm-Nd model ages and Rb-Sr isotope systematics of charnockites and gneisses across the Cauvery shear zone, southern India: Implications for the Archaean-Neoproterozoic boundary in the southern granulite terrain; In: Tectonics of Southern Granulite Terrain (ed.) Ranmakrishnan M, Geol Soc. India 50 297-317.

Blahut J, van Westen J and Sterlacchini S 2010 Analysis of landslide inventories for accurate prediction of debris flow source areas; Geomorphology 119(1) 36-51.

Bottero M, Comino E and Riggio V 2011 Application of the analytic hierarchy process and the analytic network process for the assessment of different wastewater treatment systems; Environ. Model. Softw. 26 1211-1224.

Brakensiek D L and Rawls W J 1983 Green-Ampt infiltration model parameters for hydrologic classification of soils; In: Proceedings of ASCE, Specialty Conference (eds) Borelli J, Hasfurther V R and Burman R D, New York, pp. 226233. 
Carrara A, Corsta G and Frattini P 2008 Comparing models of debris flow susceptibility in the alpine environment; Geomorphology 94(3-4) 353-378.

Clark C, Collins A S, Kinny P D, Timms N E and Chetty T R K 2009 SHRIMP U-Pb age constraints on charnockite magmatism and high-grade metamorphism in the Salem Block, southern India; Gondwana Res. 16(1) 27-36.

Cruden D M and Varnes D J 1996 Landslide types and processes; In: Landslides: Investigations and Mitigation (eds) Turner A K and Schuster R L, Special Report 247, Transportation Research Board, US National Research Council, Washington DC, pp. 36-75.

D'Ambrosio D, Spataro W and Iovine G 2006 Parallel genetic algorithms for optimising cellular automata models of natural complex phenomena: An application to debris-flows; Comput. Geosci. 32 861-875.

Fell R, Coromina J, Bonnard C, Cascini L, Leroi E and Savage W 2008 Guidelines for landslide susceptibility, hazard and risk zoning for land use planning; Eng. Geol. 102 8598.

Fernandez Merodo J A, Pastor M, Mira P, Tonni L, Herreros M I, Gonzalez E and Tamagnini R 2004 Modeling of diffuse failure mechanisms of catastrophic landslides; Comput. Methods Appl. Mech. Eng. 193(27-29) 29112939.

Gabet E J and Mudd S M 2006 Mobilization of debris flow from shallow landslides; Geomorphology 74 204-218.

Ghosh J G, Dewit M J and Zartman R E 2004 Age and tectonic evolution of Neoproterozoic ductile shear zones in the southern granulite terrain of India, with implications for Gondwana studies; Tectonics 23(3) 1-38.

Guzzetti F, Reichenbach P, Ardizzone F, Cardinali M and Galli M 2006 Estimating the quality of landslide susceptibility models; Geomorphology 81 166-184.

Harris N B W, Bartlett J M and Santosh M 1996 Neodymium isotope constraints on the tectonic evolution of east Gondwana; J. Southeast Asian Earth Sci. 14(3-4) 119-125.

Hungr O, McDougall S, Wise M and Cullen M 2008 Magnitude-frequency relationships of debris flows and debris avalanches in relation to slope relief; Geomorphology 96(3) 355-365.

Hürlimann M, Rickenmann D, Medina V and Bateman A 2008 Evaluation of approaches to calculate debris-flow parameters for hazard assessment; Eng. Geol. 102152 163.

Irigaray C, Ferna'ndez T, El Hamdouni R and Chaco'n J 2007 Evaluation and validation of landslide-susceptibility maps obtained by a GIS matrix method: Examples from the Betic Cordillera (southern Spain); Nat. Hazards $\mathbf{4 1}$ 61-79.

Iverson N R, Mann J E and Iverson R M 2010 Effects of soil aggregates on debris-flow mobilization: Results from ring-shear experiments; Eng. Geol. 114 84-92.

Keefer D K and Larsen M C 2007 Assessing landslide hazards; Science 316(5828) 1136-1137.

Liang W, Zhuang D, Jiang D, Pan J and Ren H 2012 Assessment of debris flow hazards using a Bayesian Network; Geomorphology 171-172 94-100.

Lorente A, Begueria S, Bathurst J C and Garcia-Ruiz J M 2003 Debris flow characteristics and relationships in the Central Spanish Pyrenees; Nat. Hazards Earth Syst. Sci. 3 683-692.
Lucà F, D'Ambrosio D, Robustelli G, Rongo R and Spataro W 2014 Integrating geomorphology, statistic and numerical simulations for landslide invasion hazard scenarios mapping: An example in the Sorrento peninsula (Italy); Comput. Geosci. 67 163-172.

Magliulo P, Di Lisio A, Russo F and Zelano A 2008 Geomorphology and landslide susceptibility assessment using GIS and bivariate statistics: A case study in southern Italy; Nat. Hazards 47 411-435.

McMillan P, Brown D J, Forster A and Winter M G 2005 Debris flow information sources; In: Scottish Road Network Landslides Study (eds) Winter M G, Macgregor F and Shackman L, The Scottish Executive, Edinburgh, pp. $25-44$.

Meyer N K, Schwanghart W, Korup O, Romstad B and Etzelmüller B 2014 Estimating the topographic predictability of debris flows; Geomorphology 207 114-125.

Neaupane K M and Piantanakulchai M 2006 Analytical network model for landslide hazard zonation; Eng. Geol. 85 281-294.

Okano K, Suwa H and Kanno T 2012 Characterization of debris flows by rainstorm condition at a torrent on the Mount Yakedake volcano, Japan; Geomorphology 136(1) 88-94.

Plavsa D, Collins A S, Foden J F, Kropinski L, Santosh M, Chetty T R K and Clark C 2012 Delineating crustal domains in peninsular India: Age and chemistry of orthopyroxene-bearing felsic gneisses in the Madurai block; Precamb. Res. 198-199 77-93.

Quan Luna B, Blahut J, van Westen C J, Sterlacchini S, van Asch T W J and Akbas S O 2011 The application of numerical debris flow modelling for the generation of physical vulnerability curves; Nat. Hazards Earth Syst. Sci. 11 2047-2060.

Saaty R W and Saaty T L 2003 Decision making in complex environments: The Analytic Hierarchy Process (AHP) for decision making and the Analytic Network Process (ANP) for decision making with dependence and feedback; Pittsburgh, PA: SuperDecisions for Software for Decision Making with Dependence and Feedback, SuperDecisions Software, Creative Decisions Foundation, Ellsworth Avenue.

Saaty T L 1980 The Analytic Hierarchy Process; McGrawHill, New York, NY.

Saaty T L 1999 Fundamentals of the analytic network process; In: Proceedings of International Symposium on Analytical Hierarchy Process, Kobe, Japan, pp. 48-63.

Saaty T L 2001 Decision Making with Dependence and Feedback: The Analytic Network Process; 2nd edn, RWS Publications, Pittsburgh, PA, 370p.

Saaty T L 2005 Theory and Applications of the Analytic Network Process; RWS Publications, Pittsburgh, PA, 352p.

Saaty T L and Vargas L G 2006 Decision Making with the Analytic Network Process; Springer Science, New York, NY, 333p.

Shieh C L, Chen Y S, Tsai Y J and Wu J H 2009 Variability in rainfall threshold for debris flow after the Chi-Chi earthquake in central Taiwan, China; Int. J. Sedim. Res. 24 177-188.

Sujatha E R, Kumaravel P and Rajamanickam G V 2012 Landslide susceptibility mapping using remotely sensed data through conditional probability analysis using seed 
cell and point sampling techniques; J. Indian Soc. Remote Sens. 40(4) 669-678.

Sujatha E R and Rajamanickam G V 2011 Landslide susceptibility mapping of Tevankarai Ar subwatershed, Kodaikkanal Taluk, India, using weighted similar choice fuzzy model; Nat. Hazards 59 401-425.

Sujatha E R and Rajamanickam G V 2015 Landslide hazard and risk mapping using weighted linear combination applied to Tevankarai Stream Watershed, Kodaikkanal, India; Hum. Ecol. Risk Assess. 21(6) 14451461.

Tang C, Zhu J, Li W L and Liang J T 2009 Rainfall triggered debris flow following the Wenchuan earthquake; Bull. Eng. Geol. Environ. 68(2) 187-194.

Tomson J K, Bhaskar Rao Y J, Vijaya Kumar $\mathrm{T}$ and Mallikharjuna Rao J 2006 Charnockite genesis across the Archaean-Proterozoic terrane boundary in the South Indian Granulite Terrain: Constraints from major-trace element geochemistry and $\mathrm{Sr}-\mathrm{Nd}$ isotopic systematics; Gondwana Res. 10(1-2) 115-127.

van Westen C J, van Asch T W J and Soeters R 2006 Landslide hazard and risk zonation - why is it still so difficult? Bull. Eng. Geol. Environ. 65 167-184.

Winter M G 2013 DS 4.4 Lead discussion: Landslides; In: Geotechnics of Hard Soils-Weak Rocks: Proc. 15th European Conference on Soil Mech. and Geotech. Eng., Athens, Greece (eds) Anagnostopoulos A, Pachakis M and Tsatsanifos C, IOS Press, Amsterdam, The Netherlands, vol. 4.

Yilmaz I 2009 A case study from Koyulhisar (Sivas-Turkey) for landslide susceptibility mapping by artificial neural networks; Bull. Eng. Geol. Environ. 68 297-306.

Zhen C, Heng L and Wong C T C 2005 Environal planning: Analytic Network Process Model for environmentally conscious construction planning; J. Constr. Eng. Manag. 131 92-101.

Corresponding editor: RAJIB MAITY 